\title{
Secondary Amine Derivatives of $p$-tert-Butylthiacalix[4]arene: Synthesis and Molecular Recognition of Phthalic Acid
}

\author{
Roman V. Nosov, and Ivan I. Stoikov ${ }^{\circledR}$ \\ Kazan Federal University, A.M. Butlerov Chemistry Institute, 420008 Kazan, Russian Federation \\ ${ }^{\circledR}$ Corresponding authorE-mail: ivan.stoikov@mail.ru
}

\begin{abstract}
New tetrasubstituted p-tert-butylthiacalix [4]arenes containing 2-, 3-, and 4-picolylamine fragments at the lower rim in 1,3-alternate conformation were synthesized. It was shown that the macrocycles synthesized are able to bind selectively phthalic acid in the series of dicarboxylic (oxalic, malonic, succinic, adipic, glutaric, fumaric, maleic, isophthalic and terephthalic) and hydroxy (glycolic and tartaric) acids.
\end{abstract}

Keywords: Thiacalix[4]arenes, synthesis, molecular recognition, dicarboxylic acid.

\section{Вторичные аминопроизводные $n$-mpem-бутилтиакаликс[4]арена: синтез и молекулярное распознавание фталевой кислоты}

\author{
Р. В. Носов, И. И. Стойков ${ }^{\circledR}$ \\ Казанский (Приволжский) федеральный университет, Химический институт им. А.М. Бутлерова, 420008 Казань, \\ Россия \\ ${ }^{\circledR}$ E-mail: ivan.stoikov@mail.ru
}

\begin{abstract}
Взаимодействием тетраакриламидного производного тиакаликс[4]арена в конфигурации 1,3-альтернат с изомерами (аминометил)пиридина, была синтезирована серия тетразамещенных по нижнему ободу тиакаликсаренов, содержащих фрагменты 2-, 3- и 4-пиколиламинов. Показано, что полученные макроцикль способны селективно связывать фталевую кислоту в ряду дикарбоновых (щавелевая, малоновая, янтарная, адипиновая, глутаровая, фумаровая, малеиновая, изофталевая, терефталевая) и гидроксикарбоновых (аликолевая, винная) кислот.
\end{abstract}

Ключевые слова: Тиакаликс[4]арены, синтез, молекулярное распознавание, дикарбоновая кислота.

\section{Introduction}

Calixarenes, ${ }^{[1]}$ crown ethers ${ }^{[2]}$ and cyclodextrins ${ }^{[3]}$ belong to the third generation of host molecules in supramolecular chemistry. (Thia)calix[n]arene derivatives are of particular interest as building blocks in the design of synthetic receptors for recognition of cations, anions and neutral molecules. ${ }^{[4-9]}$ The possibility of functionalizing the upper and lower rims of (thia)calixarene,,$^{[1,10-13]}$ and their diverse conformational isomers make (thia)calixarene derivatives attractive for the design of molecular sensors and transmitters, ${ }^{[14]}$ analytical sensors for biomimetic systems ${ }^{[15]}$ and as catalysts. ${ }^{[16]}$
The design of synthetic receptors for dicarboxylic acids $^{[17]}$ is of main interest due to the crucial role that dicarboxylic acids play in the metabolism of living organisms and biotechnology. For selective recognition of dicarboxylic acids, the structure of the receptor must contain proton donor and proton acceptor fragments. ${ }^{[18-23]}$ It is well known that pyridine is a proton-acceptor, and primary and secondary amino groups are involved in hydrogen bonding as proton donors and/or proton acceptors. ${ }^{[24]}$ The (aminomethyl) pyridine fragment contains two types of nitrogen atoms, i.e. one in pyridine ring and second in the amino group, which both is easily available. In this regard, we have synthesized 
tetrasubstituted at the lower rim p-tert-butylthiacalix[4] arenes containing 2-, 3- and 4-picolylamine fragments.

\section{Experimental}

\section{General}

${ }^{1} \mathrm{H}$ NMR spectra were recorded on the Bruker Avance-400 (400 MHz) spectrometer and ${ }^{13} \mathrm{C}$ and 2D NOESY NMR spectra were obtained on impulse spectrometer Bruker Avance II (125 MHz and $500 \mathrm{MHz}$ respectively). Chemical shifts were determined relative to the signals of residual protons of deuterated solvent $\left(\mathrm{CDCl}_{3}\right)$. The concentration of the sample solutions was 3-5\%.

Attenuated total internal reflectance IR spectra were recorded with Spectrum 400 (Perkin Elmer) Fourier spectrometer.

Absorption spectra were recorded on the Shimadzu UV-3600 UV-spectrometer. Quartz cuvettes with optical path length of 10 $\mathrm{mm}$ were used. Solutions of thiacalix[4]arenes in dichloromethane with concentration of $C=2.7 \cdot 10^{-5} \mathrm{M}$ were prepared and the spectra recorded after 10 min incubation. Efficiency of acid binding was estimated by addition of 200 -fold excess of acid to thiacalixarene in methanol. The experiment was carried out at $25^{\circ} \mathrm{C}$.

Elemental analysis was performed with Perkin Elmer 2400 Series II instrument.

The mass spectra were obtained on Bruker Ultraflex III MALDI-TOF instrument using 1,8,9-trihydroxyanthracene or 4-nitroaniline matrices.

Melting points were determined using the Boetius Block apparatus.

Additional control of the purity of compounds and monitoring of the reaction was carried out by thin-layer chromatography using Silica G, $200 \mu$ m plates, UV 254.

\section{Synthesis of Compounds 1-6}

p-tert-Butylthiacalix[4]arenes $\mathbf{1}$ and $\mathbf{2}$ of in 1,3-alternate conformation were used as initial reagents. ${ }^{[11]}$

5,11,17,23-Tetra-tert-butyl-25,27,26,28-tetrakis [N-(3propoxy)acrylamid]-2,8,14,20-tetrathiacalix[4]arene (1,3-alternate-3). Acryloyl chloride $(0.23 \mathrm{ml}, 4.20 \mathrm{mmol})$ in $30 \mathrm{ml}$ of dichloromethane was added dropwise at $0{ }^{\circ} \mathrm{C}$ to mixture of $1.00 \mathrm{~g}$ $(1.05 \mathrm{mmol})$ of 5,11,17,23-tetra-tert-butyl-25,27,26,28-tetra[aminopropoxy]-2,8,14,20-tetrathiacalix[4]arene 2, $20 \mathrm{mg}$ of 4-methoxyphenol and $40 \mathrm{ml}$ of dichloromethane in the $100 \mathrm{ml}$ three necked round bottom flask equipped with magnetic stirrer and dropping funnel. The reaction mixture was then stirred for $2 \mathrm{hrs}$ at low temperature and then $40 \mathrm{hrs}$ at r.t. White precipitate (triethylamine hydrochloride) was filtered off and the resulting solution was washed with water until the $\mathrm{p} H$ of the aqueous layer became neutral. The organic solvent was then rotary evaporated and the solid residue recrystallized from mixture of ethanol-trichloromethane to isolate thiacalixarene 3. Yield $0.89 \mathrm{~g}(73 \%)$. M.p. $189^{\circ} \mathrm{C} .{ }^{1} \mathrm{H} \mathrm{NMR}\left(\mathrm{CDCl}_{3}\right)$ $\delta_{\mathrm{H}}$ ppm: $1.21 \mathrm{~s}\left(36 \mathrm{H},\left(\mathrm{CH}_{3}\right)_{3} \mathrm{C}\right) ; 1.32 \mathrm{~m}\left(8 \mathrm{H},\left(\mathrm{CH}_{2}-\mathrm{CH}_{2}-\mathrm{CH}_{2}\right) ; 3.04 \mathrm{~m}\right.$ $\left(8 \mathrm{H}, \mathrm{CH}_{2}-\mathrm{NH}-\mathrm{C}(\mathrm{O})\right) ; 3.85 \mathrm{t}\left(8 \mathrm{H}, \mathrm{O}-\mathrm{CH}_{2},{ }^{3} \mathrm{~J}_{\mathrm{HH}}=7.1 \mathrm{~Hz}\right) ; 5.63 \mathrm{~m} \mathrm{X}$ part of ABX system $\left(4 \mathrm{H},-\mathrm{CH}_{2}=\mathrm{CH},{ }^{2} J_{\mathrm{HH}}=2.6 \mathrm{~Hz}\right) ; 6.20$ part A of ABX system qd $\left(4 \mathrm{H}, \mathrm{CH}_{2}=\mathrm{CH}_{-}{ }^{3} \mathrm{~J}_{\mathrm{HH}}=12.3 \mathrm{~Hz},{ }^{2} \mathrm{~J}_{\mathrm{HH}}=0.3 \mathrm{~Hz}\right) ; 6.20$ part B of $\mathrm{ABX}$ system qd ( $\left.4 \mathrm{H}, \mathrm{CH}_{2}=\mathrm{CH},{ }^{3} \mathrm{~J}_{\mathrm{HH}}=12.3 \mathrm{~Hz},{ }^{2} \mathrm{~J}_{\mathrm{HH}}=0.3 \mathrm{~Hz}\right) ; 6.44$ br.t (4H, NH); $7.31 \mathrm{~s}(8 \mathrm{H}, \mathrm{Ar}-\mathrm{H}) .{ }^{13} \mathrm{C}$ NMR $\left(\mathrm{CDCl}_{3}\right) \delta_{\mathrm{C}} \mathrm{ppm}$ : 29.28; $31.22 ; 34.27 ; 36.98 ; 67.03 ; 126.19 ; 127.60 ; 128.07 ; 130.98 ; 146.15$; 156.74; 165.61. IR $v \mathrm{~cm}^{-1}: 3276(\mathrm{NH}) ; 1656(\mathrm{C}(\mathrm{O})-\mathrm{NH}) ; 1629$, 1544 (C(O)-NH). Mass-spectrum (MALDI-TOF): calculated $m / z=$ 1164.4, found $m / z=1165.6\left(\mathrm{M}+\mathrm{H}^{+}\right)$. Elemental analysis. Calculated (\%): C, 65.95; H, 7.26; N, 4.81; S, 11.00 for $\mathrm{C}_{64} \mathrm{H}_{84} \mathrm{~N}_{4} \mathrm{O}_{8} \mathrm{~S}_{4}$. Found (\%): C, 66.02; H, 7.32; N, 4.92; S, 11.13.

5,11,17,23-Tetra-tert-butyl-25,27,26,28-tetrakis $[N-(3-$ propoxy)-3-(pyridine-2-methylamino)propanamide]-2,8,14,20- tetrathiacalix [4] arene (1,3-alternate-4). 2-Picolylamine $(0.15 \mathrm{ml}$, $1.39 \mathrm{mmol})$ in methanol $(10 \mathrm{ml})$ was added to $5,11,17,23$-tetra-tertbutyl-25,27,26,28-tetrakis[ $N$-(3-propoxy)acrylamide]-2,8,14,20tetrathiacalix[4]arene $3(0.1 \mathrm{~g}, 0.08 \mathrm{mmol})$. The reaction mixture was refluxed for $60 \mathrm{hrs}$ under argon, and then the solvent was rotary evaporated. The precipitate was washed with water. Yield $0.12 \mathrm{~g}(88 \%)$. M.p. $113^{\circ} \mathrm{C} .{ }^{1} \mathrm{H}$ NMR $\left(\mathrm{CDCl}_{3}\right) \delta_{\mathrm{H}}$ ppm: $1.20 \mathrm{~s}(36 \mathrm{H}$, $\left.\left(\mathrm{CH}_{3}\right)_{3} \mathrm{C}\right) ; 1.25 \mathrm{~m}\left(8 \mathrm{H},\left(-\mathrm{CH}_{2}-\mathrm{CH}_{2}-\mathrm{CH}_{2}\right) ; 2.15\right.$ br.s. $\left(4 \mathrm{H}, \mathrm{CH}_{2}-\mathrm{NH}-\right.$ $\left.\mathrm{CH}_{2}\right) ; 2.36 \mathrm{t}\left(8 \mathrm{H},-\mathrm{CH}_{2}-\mathrm{CH}_{2}-\mathrm{NH}-\mathrm{CH}_{2},{ }^{3} J_{\mathrm{HH}}=5.9 \mathrm{~Hz}\right) ; 2.86 \mathrm{t}(8 \mathrm{H}$, $\left.-\mathrm{CH}_{2}-\mathrm{NH}-\mathrm{CH}_{2},{ }^{3} \mathrm{~J}_{\mathrm{HH}}=6.1 \mathrm{~Hz}\right) ; 2.95 \mathrm{~m}\left(8 \mathrm{H},-\mathrm{CH}_{2}-\mathrm{NH}-\mathrm{C}(\mathrm{O})\right) ; 3.81 \mathrm{~s}$ $\left(8 \mathrm{H},-\mathrm{NH}-\mathrm{CH}_{2}-\mathrm{Py}\right) ; 3.82 \mathrm{~m}\left(8 \mathrm{H},-\mathrm{CH}_{2}-\mathrm{NH}-\mathrm{C}(\mathrm{O}) ; 7.19-8.54 \mathrm{~m}\right.$ $(16 \mathrm{H}, \mathrm{PyH}) ; 7.29 \mathrm{~s}(8 \mathrm{H}, \mathrm{Ar}-\mathrm{H}) ; 7.38$ br.t $(4 \mathrm{H}, \mathrm{NH}-\mathrm{C}(\mathrm{O})) .{ }^{13} \mathrm{C} \mathrm{NMR}$ $\left(\mathrm{CDCl}_{3}\right) \delta_{\mathrm{C}}$ ppm: 172.27, 158.12, 156.67, 149.43, 145.94, 136.66, $128.10,127.65,122.50,122.33,66.70,54.20,45.17,36.49,35.11$, 34.23, 31.22, 29.08. IR $v \mathrm{~cm}^{-1}: 3277(\mathrm{NH}) ; 3062(\mathrm{NH}) ; 1639(\mathrm{C}(\mathrm{O})-$ $\mathrm{NH}) ; 1544,1568$ (C(O)-NH). Mass-spectrum (MALDI-TOF): calculated $m / z=1598.2$, found $m / z=1598.4\left(\mathrm{M}+\mathrm{H}^{+}\right)$. Elemental analysis. Calculated (\%): C, 66.13; H, 7.32; N, 10.52; S, 8.02 for $\mathrm{C}_{88} \mathrm{H}_{116} \mathrm{~N}_{12} \mathrm{O}_{8} \mathrm{~S}_{4}$. Found (\%): C, 66.18; H, 7.45; N, 10.64; S, 8.07.

$5,11,17,23$-Tetra-tert-butyl-25,27,26,28-tetrakis [N-(3propoxy)-3-(pyridine-3-methylamino)propanamide]-2,8,14,20tetrathiacalix[4]arene (1,3-alternate-5). 3-Picolylamine $(0.7 \mathrm{ml}$, $6.9 \mathrm{mmol})$ in methanol $(10 \mathrm{ml})$ was added to 5,11,17,23-tetra-tertbutyl-25,27,26,28-tetrakis[ $N$-(3-propoxy)acrylamide]-2,8,14,20tetrathiacalix[4]arene $3(0.5 \mathrm{~g}, 0.43 \mathrm{mmol})$. The reaction mixture was refluxed for $20 \mathrm{hrs}$ under argon, and then the solvent was rotary evaporated. The precipitate was washed with water. Yield $0.61 \mathrm{~g}(88 \%)$. M.p. $133{ }^{\circ} \mathrm{C} .{ }^{1} \mathrm{H}$ NMR $\left(\mathrm{CDCl}_{3}\right) \delta_{\mathrm{H}} \mathrm{ppm}: 1.20 \mathrm{~s}(36 \mathrm{H}$, $\left.\left(\mathrm{CH}_{3}\right)_{3} \mathrm{C}\right) ; 1.23 \mathrm{~m}\left(8 \mathrm{H},\left(-\mathrm{CH}_{2}-\mathrm{CH}_{2}-\mathrm{CH}_{2}\right) ; 2.31\right.$ br.s. $\left(4 \mathrm{H}, \mathrm{CH}_{2}-\right.$ $\left.\mathrm{NH}-\mathrm{CH}_{2}\right) ; 2.39 \mathrm{t}\left(8 \mathrm{H},-\mathrm{CH}_{2}-\mathrm{CH}_{2}-\mathrm{NH}-\mathrm{CH}_{2},{ }^{3} \mathrm{~J}_{\mathrm{HH}}=6.0 \mathrm{~Hz}\right) ; 2.90 \mathrm{t}$ $\left(8 \mathrm{H},-\mathrm{CH}_{2}-\mathrm{NH}-\mathrm{CH}_{2},{ }^{3} \mathrm{~J}_{\mathrm{HH}}=6.0 \mathrm{~Hz}\right) ; 2.99 \mathrm{~m}\left(8 \mathrm{H},-\mathrm{CH}_{2}-\mathrm{NH}-\mathrm{C}(\mathrm{O})\right)$; $3.82 \mathrm{t}\left(8 \mathrm{H},-\mathrm{CH}_{2}-\mathrm{NH}-\mathrm{C}(\mathrm{O}),{ }^{3} \mathrm{~J}_{\mathrm{HH}}=6.0 \mathrm{~Hz}\right) ; 3.94 \mathrm{~s}\left(8 \mathrm{H},-\mathrm{NH}-\mathrm{CH}_{2}-\right.$ Py); 7.26-8.54 m (16H, PyH); 7.28 s $(8 \mathrm{H}, \mathrm{Ar}-\mathrm{H}) ; 7.85$ br. t $(4 \mathrm{H}$, $\mathrm{NH}-\mathrm{C}(\mathrm{O})) .{ }^{13} \mathrm{C} \mathrm{NMR}\left(\mathrm{CDCl}_{3}\right) \delta_{\mathrm{C}} \mathrm{ppm}: 172.05,156.63,149.77$, $148.72,145.98,135.84,134.86,128.07,127.62,123.46,66.69$, $50.88,44.99,36.49,35.45,34.23,31.21,29.22$. IR $v \mathrm{~cm}^{-1}: 3281$, $3055(\mathrm{NH}) ; 1643(\mathrm{C}(\mathrm{O})-\mathrm{NH}) ; 1543,(\mathrm{C}(\mathrm{O})-\mathrm{NH})$. Mass spectrum (MALDI-TOF): calculated $\mathrm{m} / \mathrm{z}=1598.2$, found $\mathrm{m} / \mathrm{z}=1598.3$ $\left(\mathrm{M}+\mathrm{H}^{+}\right)$. Elemental analysis. Calculated (\%): C, 66.13; H, 7.32; $\mathrm{N}, 10.52 ; \mathrm{S}, 8.02$ for $\mathrm{C}_{88} \mathrm{H}_{116} \mathrm{~N}_{12} \mathrm{O}_{8} \mathrm{~S}_{4}$. Found (\%): C, 66.17; H, 7.40; N, 10.58; S, 8.21.

5,11,17,23-Tetra-tert-butyl-25,27,26,28-tetrakis [N-(3propoxy)-3-(pyridine-4-methylamino)propaneamide]-2, 8, 14,20 tetrathiacalix[4]arene (1,3-alternate-6). 4-Picolylamine $(0.7 \mathrm{ml}$, $6.9 \mathrm{mmol})$ in methanol $(40 \mathrm{ml})$ was added to $5,11,17,23$-tetra-tertbutyl-25,27,26,28-tetrakis[ $N$-(3-propoxy)acrylamide]-2,8,14,20tetrathiacalix[4]arene $3(0.5 \mathrm{~g}, 0.43 \mathrm{mmol})$. The reaction mixture was refluxed for $17 \mathrm{hrs}$ under argon, and then the solvent was rotary evaporated. The residue was washed with water. Yield $0.65 \mathrm{~g}(94 \%)$. M.p. $145{ }^{\circ} \mathrm{C} .{ }^{1} \mathrm{H}$ NMR $\left(\mathrm{CDCl}_{3}\right) \delta_{\mathrm{H}}$ ppm: $1.22 \mathrm{~s}$ $\left(36 \mathrm{H},\left(\mathrm{CH}_{3}\right)_{3} \mathrm{C}\right) ; 1.24 \mathrm{~m}\left(8 \mathrm{H},\left(-\mathrm{CH}_{2}-\mathrm{CH}_{2}-\mathrm{CH}_{2}\right) ; 2.14\right.$ br. s $(4 \mathrm{H}$, $\left.\mathrm{CH}_{2}-\mathrm{NH}-\mathrm{CH}_{2}\right) ; 2.38$ t $\left(8 \mathrm{H},-\mathrm{CH}_{2}-\mathrm{CH}_{2}-\mathrm{NH}-\mathrm{CH}_{2},{ }^{3} \mathrm{~J}_{\mathrm{HH}}=5.6 \mathrm{~Hz}\right)$; $2.87 \mathrm{t}\left(8 \mathrm{H},-\mathrm{CH}_{2}-\mathrm{NH}-\mathrm{CH}_{2},{ }^{3} \mathrm{~J}_{\mathrm{HH}}=5.8 \mathrm{~Hz}\right) ; 2.97 \mathrm{~m}\left(8 \mathrm{H},-\mathrm{CH}_{2}-\mathrm{NH}-\right.$ $\mathrm{C}(\mathrm{O})) ; 3.82 \mathrm{~s}\left(8 \mathrm{H},-\mathrm{NH}-\mathrm{CH}_{2}-\mathrm{Py}\right) ; 3.84 \mathrm{~m}\left(8 \mathrm{H},-\mathrm{CH}_{2}-\mathrm{NH}-\mathrm{C}(\mathrm{O})\right.$, $\left.{ }^{3} J_{\mathrm{HH}}=6.9 \mathrm{~Hz}\right) ; 7.23-8.51 \mathrm{~m}(16 \mathrm{H}, \mathrm{PyH}) ; 7.30 \mathrm{~s}(8 \mathrm{H}, \mathrm{Ar}-\mathrm{H}) .{ }^{13} \mathrm{C}$ NMR $\left(\mathrm{CDCl}_{3}\right) \delta_{\mathrm{C}} \mathrm{ppm}: 171.83,156.53,150.08,146.03,128.09$, 127.66, 123.12, 66.75, 52.10, 44.98, 36.60, 34.95, 34.25, 31.22, 29.23. IR $v \mathrm{~cm}^{-1}: 3280(\mathrm{NH}) ; 1640(\mathrm{C}(\mathrm{O})-\mathrm{NH}) ; 1601,1544(\mathrm{C}(\mathrm{O})-$ $\mathrm{NH}$ ). Mass-spectrum (MALDI-TOF): calculated $\mathrm{m} / \mathrm{z}=1598.2$, found $m / z=1598.7\left(\mathrm{M}+\mathrm{H}^{+}\right)$. Elemental analysis. Calculated (\%): C, 66.13; H, 7.32; N, 10.52; S, 8.02 for $\mathrm{C}_{88} \mathrm{H}_{116} \mathrm{~N}_{12} \mathrm{O}_{8} \mathrm{~S}_{4}$. Found (\%): C, 66.32; H, 7.46; N, 10.75; S, 8.10.

\section{Determination of Stability Constant and Stoichiometry of the Complex by UV Titration}

The UV measurements were performed with Shimadzu UV-3600 instrument. The $1.65 \cdot 10^{-3} \mathrm{M}$ solution of dicarboxylic 
acid (oxalic, malonic, succinic, adipic, glutaric, fumaric, maleic, isophthalic, or terephthalic acid) or hydroxy (glycolic or tartaric) acid $(100,150,200,250,300,400,450,500,550,600,700,800$, $900 \mu \mathrm{l})$ in methanol was added to $1 \mathrm{ml}$ of the solution of receptor 4-6 $\left(8.3 \cdot 10^{-5} \mathrm{M}\right)$ in methanol and finally diluted to $3 \mathrm{ml}$ with methanol. The UV spectra of the solutions obtained were then recorded. The stability constants and stoichiometry of complexes were calculated as described elsewhere. ${ }^{[25]}$ Three independent experiments were carried out for each series. Student's $t$-test was applied in statistical data processing.

\section{Results and Discussion}

\section{Synthesis of Thiacalix[4]arenes}

Among various approaches developed for the synthesis of aminocalixarenes containing primary amino groups including the reduction of nitro compounds, ${ }^{[26]}$ nitriles ${ }^{[27,28]}$ cleavage of phthalimide derivatives, ${ }^{[11]}$ the synthesis of secondary amine derivatives based on calixarenes is less studied. ${ }^{[29,30]}$

An alternative approach to the preparation of thiacalixarene containing secondary amino groups, based on conjugate addition of amines to $\alpha$-, $\beta$-unsaturated compounds (aza-Michael reaction) was used. This method has attracted much attention due to its mildness and operation simplicity. ${ }^{[31]}$ The spatial orientation of the four macrocycle substituents about the plane of calixarene makes the 1,3-alternate conformation interesting for the synthesis of receptors for dicarboxylic and hydroxycarboxylic acids. Also in the 1,3-alternate conformation, allosteric effect can be realized. ${ }^{[32]}$

To introduce secondary and tertiary amino groups into the structure of a compound, the aza-Michael reaction can be used. ${ }^{[31]}$ Previously, the derivatives $\mathbf{1}$ and $\mathbf{2}$ of tetrasubstituted at lower rim thiacalix[4]arene in 1,3-alternate conformation containing the phthalimide and primary amino fragments, respectively, were synthesized. ${ }^{[11]}$ The interaction of $p$-tert-butyl-thiacalix[4] arene 2 with acryloyl chloride in the presence of triethylamine and 4-methoxyhydroquinone as a radical polymerization stabilizer resulted in formation of tetraacrylamide 3 in 1,3-alternate conformation (Scheme 1).

The $p$-tert-butyl-thiacalix[4]arene was further functionalized with (aminomethyl)pyridine fragments by the reaction of the macrocycle 3 and (aminomethyl)pyridine isomers, (2-, 3-, 4-(aminomethyl)pyridine) (Scheme 2).

The reaction was carried out under inert atmosphere to prevent the oxidation of amines. It should be noted that the reaction time depended on the amine used (Table 1). In the case of 3-and 4-picolylamine the reaction time did not significantly differ (20 and 17 hours, respectively). However, the complete conversion of the macrocycle $\mathbf{3}$ in the presence of 2-picolylamine took 60 hours of refluxing. Difference in the reaction rate in the case of 2-picolylamine is due to the reduced nucleophilicity of the primary amine group resulting from the proximity to the electron-acceptor nitrogen of pyridine. Complete conversion of the compound 3 was monitored using TLC and ${ }^{1} \mathrm{H}$ NMR spectroscopy.

Figure 1 shows the ${ }^{1} \mathrm{H}$ NMR spectra of parent macrocycle 3 and reaction products. Absence of signals for the $\mathrm{ABX}$ system of acrylamide groups in the macrocycle $\mathbf{3}$ as well as the appearance of new signals at $7.5 \mathrm{ppm}$ and 3.5 ppm, clearly confirms complete conversion of the compound $\mathbf{3}$ in the reaction products 4-6.

Table 1. Reaction time and yields of macrocycles 4-6.

\begin{tabular}{ccc}
\hline Compound & Yields, $\%$ & Reaction time, $\mathrm{h}$. \\
\hline $\mathbf{4}$ (2-isomer) & 88 & 60 \\
$\mathbf{5}$ (3-isomer) & 88 & 20 \\
$\mathbf{6}$ (4-isomer) & 94 & 17 \\
\hline
\end{tabular}

Table 2 shows the characteristic stretching vibrations of macrocycles 3-6 in the IR spectra. From the analysis of IR spectra, it can be observed that the amide protons of the macrocycles 3-6 are in the associated form. Offset of stretching bands of the carbonyl group (-C(O)-) of the synthesized (aminomethyl)pyridines 4-6 in comparison with the thiacalixarene $\mathbf{3}$ is due to the disappearance of a multiple bond $(\mathrm{C}=\mathrm{C})$ in the thiacalixarenes 4-6.

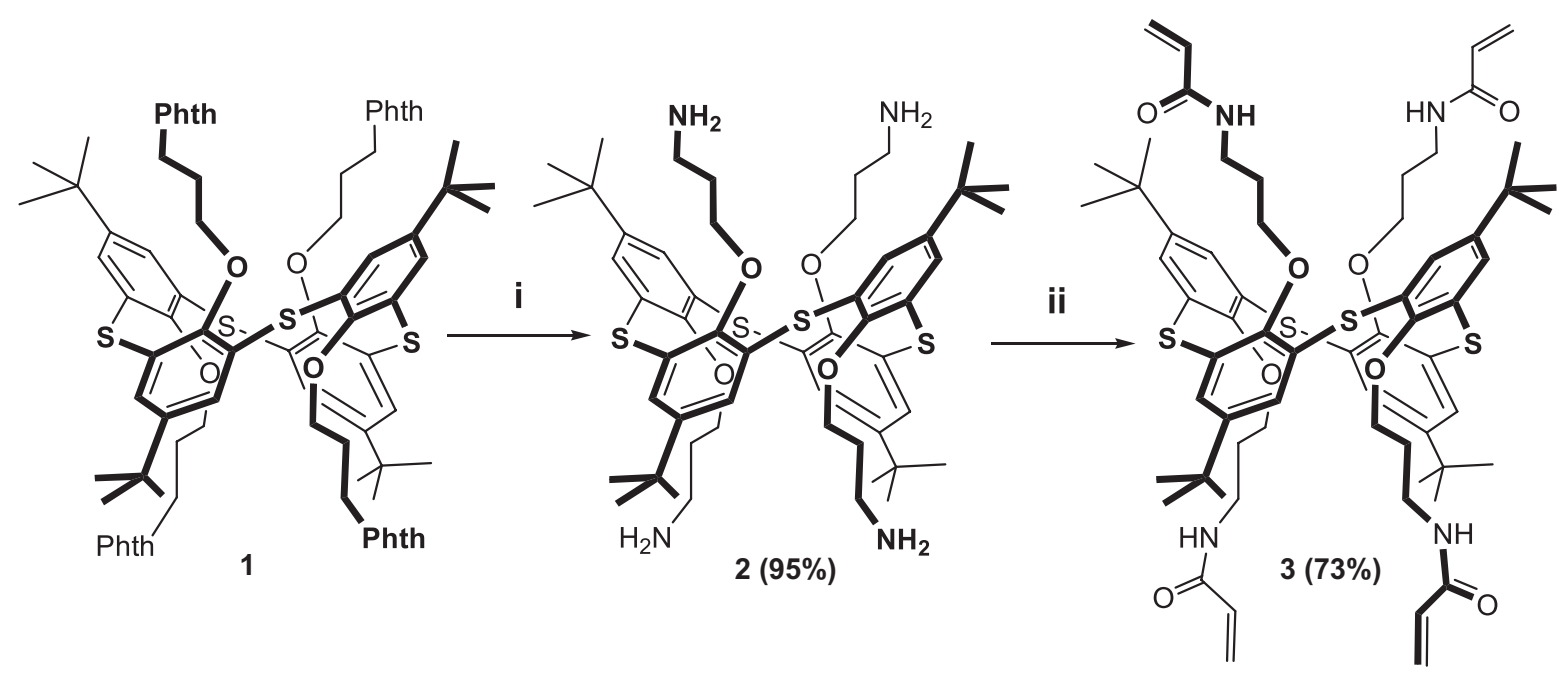

Scheme 1. Reagents and conditions: (i) $\mathrm{NH}_{2} \mathrm{NH}_{2} \cdot \mathrm{H}_{2} \mathrm{O}, \mathrm{C}_{2} \mathrm{H}_{5} \mathrm{OH} / \mathrm{THF}$; (ii) acryloyl chloride, 4-methoxyhydroquinone, $\mathrm{CH}_{2} \mathrm{Cl}_{2} / \mathrm{NEt}_{3}$. 

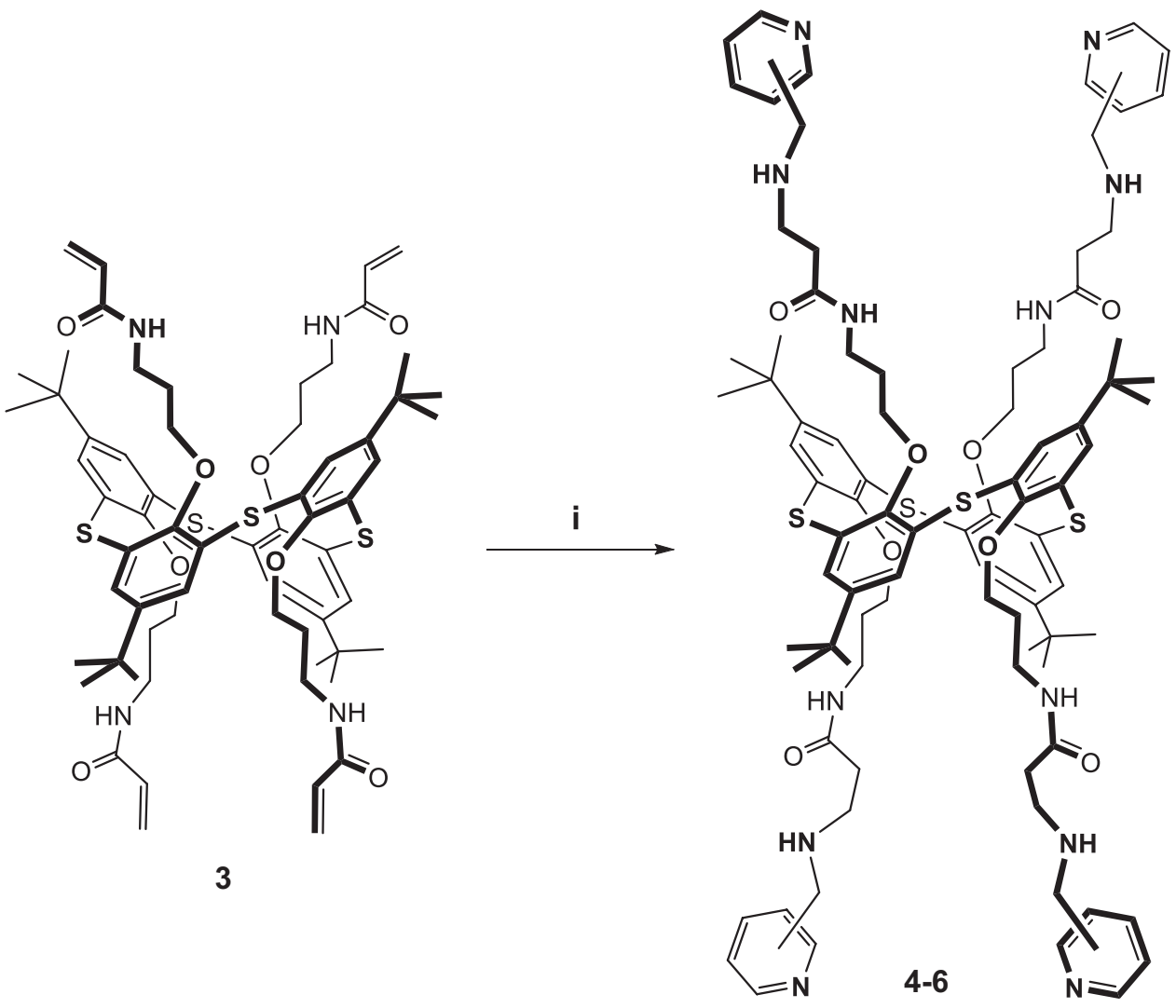

Scheme 2. Reagents and conditions: (i) 2-, 3- or 4-(aminomethyl)pyridine $\mathrm{CH}_{3} \mathrm{OH} / \mathrm{THF}$ (see Table 1).

Table 2. The values of valence vibrations for macrocycles 3-6 in the IR spectra.

\begin{tabular}{ccc}
\hline Compound & $v(-\mathrm{C}(\mathrm{O}) \mathrm{NH}-), \mathrm{cm}^{-1}$ & $v(-\mathrm{C}(\mathrm{O})-), \mathrm{cm}^{-1}$ \\
\hline $\mathbf{3}$ & 3278,3073 & 1656 \\
$\mathbf{4}$ & 3277,3063 & 1639 \\
$\mathbf{5}$ & 3280,3063 & 1643 \\
$\mathbf{6}$ & 3281,3056 & 1641 \\
\hline
\end{tabular}

Thus, for the first time, p-tert-butylthiacalix[4] arene derivatives containing acrylamide and 2-, 3-, and 4-(aminomethyl)pyridine moieties were synthesized. The structure and composition of the compounds 3-6 was confirmed by physical and chemical methods: NMR ${ }^{1} \mathrm{H}$, ${ }^{13} \mathrm{C}$, IR spectroscopy, MALDI-TOF mass spectrometry and elemental analysis.

\section{Complexation Study of p-tert-Butylthiacalix[4]arenes 4-6 by UV Spectroscopy}

The efficiency and selectivity of the interaction of the obtained macrocycles 4-6 with glutamic, aspartic, tartaric, oxalic, glycolic, malonic, succinic, fumaric, maleic, phthalic, isophthalic and terephthalic acids were established by UV spectroscopy.

Interestingly, the synthesized macrocycles 4-6 showed analytical response only to phthalic acid. Figure 2 shows the

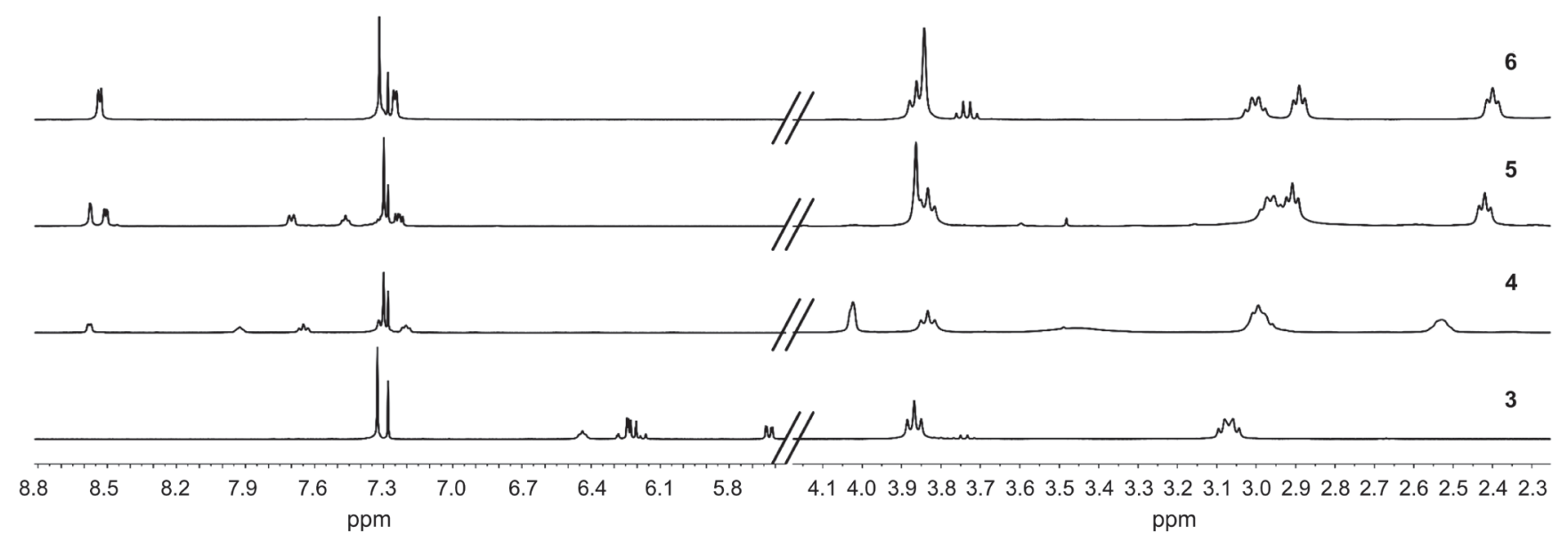

Figure 1. ${ }^{1} \mathrm{H}$ NMR spectra of compounds 3-6 $\left(\mathrm{CDCl}_{3}\right.$, at $25^{\circ} \mathrm{C}$, Bruker Avance-400). 
absorbance spectrum for the interaction of the macrocycle 4 with 200-fold excess of phthalic acid. Addition of phthalic acid to the macrocycle 4 resulted in the hypochromic effect and the bathochromic shift of the absorption band to $290 \mathrm{~nm}$ and the appearance of a new absorption maximum at $275 \mathrm{~nm}$.

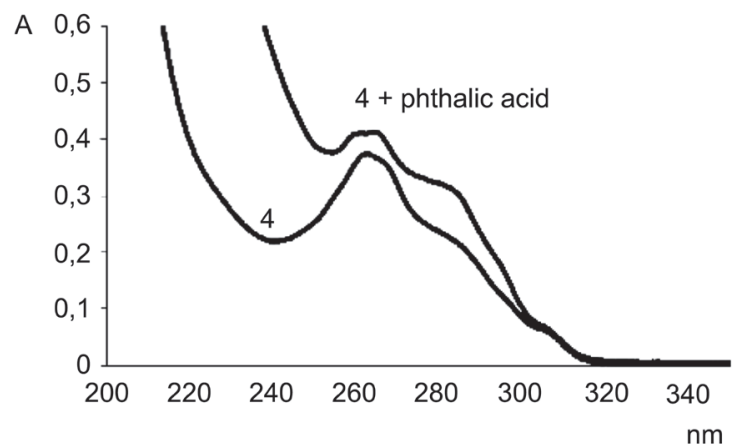

Figure 2. UV spectrum of $p$-tert-butyl-thiacalix[4]arene 4 $\left(C=2.7 \cdot 10^{-5} \mathrm{M}\right)$ after addition of phthalic acid in methanol.

It should be noted that a similar pattern is observed for the interaction of the macrocycles $\mathbf{5}$ and $\mathbf{6}$ with phthalic acid. This indicates that the binding process is the same for all the synthesized macrocycles 4-6.

To qualitatively determine the complexing ability of the macrocycles 4-6 to the phthalic acid, association constants were determined (Table 3). Using the method of isomolar series, it was established that the macrocycles 4-6 complexed phthalic acid at a ratio of 1:1 in methanol (Figure 3). Calculation of the association constants (Table 3) was carried out by the Benesi-Hildebrand method. ${ }^{[25]}$

The proposed scheme for the binding of phthalic acid by the macrocycles 4-6 is shown in Figure 3. The apparent
Table 3. The logarithms of the association constant $\left(\lg K_{\text {ass }}\right)$ for the receptors 4-6 with phthalic acid, the stoichiometry of the host:guest complexes is $1: 1$.

\begin{tabular}{cc}
\hline Compound & $-\lg \left(K_{\mathrm{as}}\right)$ \\
\hline $\mathbf{4}$ & $4.38 \pm 0.19$ \\
$\mathbf{5}$ & $4.10 \pm 0.04$ \\
$\mathbf{6}$ & $4.08 \pm 0.08$ \\
\hline
\end{tabular}

identical association constant values for the macrocycles 4-6 with phthalic acid is due to the absolute involvement of pyridine fragments in binding of phthalic acid. The 1:1 stoichiometry of complexes is due to negative allosteric effect.

It should be noted that these systems can be used to construct effective ternary systems for detecting metal cations or to realize supramolecular self-assembly. ${ }^{[33,34]}$

\section{Conclusion}

We have proposed and implemented a new strategy for obtaining aminothiacalixarene receptors for carboxylic acids, based on the aza-Michael addition reaction. Novel tetrasubstituted at the lower rim $p$-tert-butylthiacalix[4]arenes in the 1,3-alternate conformation containing 2-, 3- and 4-picolylamines have been synthesized. Molecular recognition of phthalic acid in a series of dicarboxylic (oxalic, malonic, succinic, adipic, glutaric, fumaric, maleic, isophthalic, and terephthalic) and hydroxy (glycolic and tartaric) acids by the macrocycles synthesized was demonstrated.

Acknowledgements. This work was funded by the subsidy allocated to Kazan Federal University for the state assignment in the sphere of scientific activities.
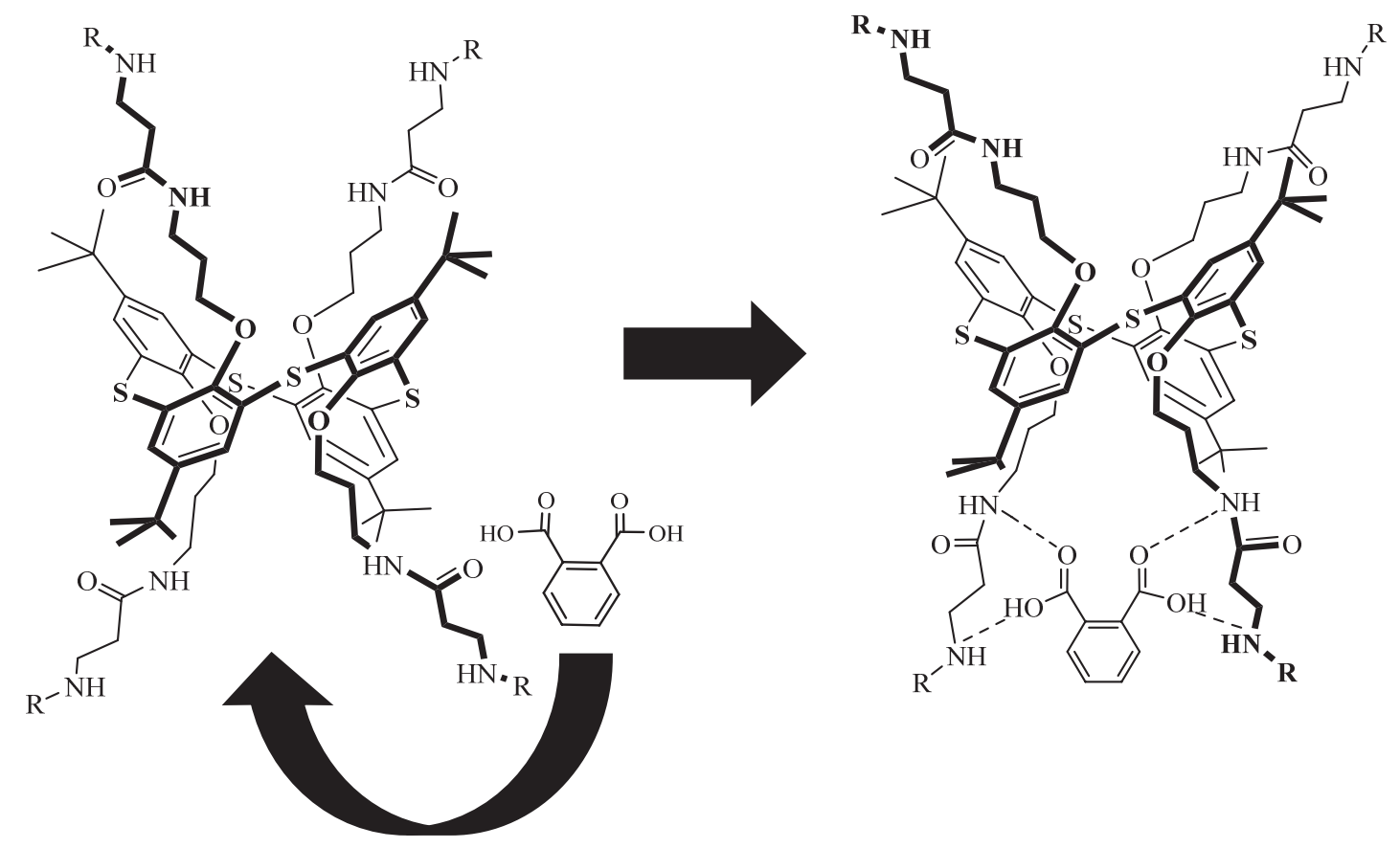

Figure 3. Proposed scheme for the interaction of thiacalix[4]arenes 4-6 with phthalic acid. 


\section{References}

1. Morohashi N., Narumi F., Iki N., Hattori T., Miyano S. Chem. Rev. 2006, 106, 5291-5316.

2. George W., Gokel W., Matthew L., Michelle E.W. Chem. Rev. 2004, 104, 2723-2750.

3. Del Valle M.E.M. Process Biochem. 2004, 39, 1033-1046.

4. Jung H.S., Kim H.J., Vicens J., Kim J.S. Tetrahedron Lett. 2009, 50, 983-987.

5. Ni X.L., Zeng X., Redshaw C., Yamato T. Tetrahedron 2011, $67,3248-3253$

6. Galukhin A.V., Andreyko E.A., Rizvanov I.H., Stoikov I.I. Mendeleev Commun. 2013, 23, 196-198.

7. Stoikov I.I., Yantemirova A.A., Nosov R.V., Rizvanov I.Kh., Julmetov A.R., Klochkov V.V., Antipin I.S., Konovalov A.I., Zharov I. Org. Biomol. Chem. 2011, 9, 3225-3234.

8. Kas M., Lang K., Stibor I., Lhotak P. Tetrahedron Lett. 2007, 48, 477-481.

9. Galukhin A.V., Shabalin K.V., Antipin I.S., Konovalov A.I., Stoikov I.I. Mendeleev Commun. 2013, 23, 41-43.

10. Stoikov I.I., Yantemirova A.A., Nosov R.V., Julmetov A.R., Klochkov V.V., Antipin I.S., Konovalov A.I. Mendeleev Commun. 2011, 21, 41-43.

11. Galukhin A.V., Zaikov E.N., Antipin I.S., Konovalov A.I., Stoikov I.I. Macroheterocycles 2012, 5, 266-274.

12. Vavilova A.A., Nosov R.V., Yagarmina A.N., Mostovaya O.A., Antipin I.S., Konovalov A.I., Stoikov I.I. Macroheterocycles 2012, 5, 396-403.

13. Muniyappan R.G., Yamada M., Yoshihiko K., Ryo S., Fumio H. Ind. Eng. Chem. Res. 2014, 53(7), 2559-2565.

14. Mostovaya O., Agafonova M., Galukhin A., Khayrutdinov B., Islamov D., Kataeva O., Antipin I., Konovalov A., Stoikov I. J. Phys. Org. Chem. 2014, 27, 57-65.

15. Baldini L., Cacciapaglia R., Casnati A., Mandolini L., Salvio R., Sansone F., Ungaro R. J. Org. Chem. 2012, 77, 33813389.
16. Homden D.M., Redshaw C. Chem. Rev. 2008, 108, 5086-5130.

17. Fitzmaurice R.J., Kyne G.M., Douheret D., Kilburn J.D. J. Chem. Soc., Perkin Trans. 1 2002, 841-864.

18. Santis G.D., Fabbrizzi L., Licchelli M., Poggi A., Taglietti A. Angew. Chem., Int. Ed. Engl. 1996, 35, 202-204.

19. Beer P.D., Gale P.A. Angew. Chem., Int. Ed. 2001, 40, 486-516.

20. Izatt R.M., Pawlak K., Bradshaw J.S., Bruening R.L. Chem. Rev. 1991, 91, 1721-2085.

21. Andreyko E.A., Padnya P.L., Daminova R.R., Stoikov I.I. RSC $A d v$. 2014, 4, 3556-3565.

22. Andreyko E.A., Stoikov I.I., Antipin I.S., Karpus A.O., Sikorsky A.M., Yesypenko O.A., Rozhenko A.B., Boyko V.I., Kalchenko V.I. Macroheterocycles 2013, 6, 227-233.

23. Agafonova M.N., Mostovaya O.A., Antipin I.S., Konovalov A.I., Stoikov I.I. Mendeleev Commun. 2012, 22, 80-82.

24. Etter M.C. J. Phys. Chem. 1991, 95, 4601-4610.

25. Hirose K. J. Inkl. Phenom. Macroc. Chem. 2001, 39, 193-209.

26. Pelizzi N., Casnati A., Friggeri A., Ungaro R. J. Chem. Soc., Perkin Trans. 1998, 2, 1307-1311.

27. Wolf N.J., Georgiev E.M., Yordanov A.T., Whittlesey B.R., Koch H.F., Roundhill D.M. Polyhedron 1999, 18, 885-896.

28. Budka J., Tkadlecova M., Lhota'ka P., Stibor I. Tetrahedron 2000, 56, 1883-1887.

29. Quintard A., Darbost U., Vocanson F., Pellet-Rostaing S., Lemaire M. Tetrahedron: Asymmetry 2007, 18, 1926-1933.

30. O'Toole L., Creavenb B.S., McGinley J. Dalton Trans. 2014, 43, 8387-8394.

31. Enders D., Wang C., Liebich J.X. Chem. Eur. J. 2009, 15, 11058-11076.

32. Willans C.E., Anderson K.M., Pottsb L.C., Steed J.W. Org. Biomol. Chem. 2009, 7, 2756-2760.

33. Yushkova E.A., Stoikov I.I. Zhukov A., Puplampu J.B., Rizvanov I.K., Antipin I.S., Konovalov A. RSC $A d v$. 2012, 2, 39063919.

34. Yushkova E.A., Stoikov I.I.,Puplampu J.B.,Antipin I.S., Konovalov A.I. Langmuir 2011, 27, 14053-14064. 